AUTHOR:

Letlhoyo Segalo (i)

https://orcid.org/0000-0001-8625-6450

AFFILIATION:

Department of Educational and

Professional Studies

Faculty of Humanities

Central University of Technology

CORRESPONDENCE TO:

Isegalo@cut.ac.za

DATES:

Published: 10 December 2020

HOW TO CITE THIS ARTICLE:

Segalo, L.J., 2020. The Learner

pregnancy in secondary schools

in South Africa: Has attitudes and

perceptions of teachers changed?

KOERS - Bulletin for Christian

Scholarship, 85(1). Available at: https://

doi.org/10.19108/KOERS.85.1.2461

COPYRIGHT:

(c) 2020. The Author(s).

Published under the Creative

Commons Attribution License.

\section{Learner pregnancy in secondary schools in South Africa: Have attitudes and perceptions of teachers changed?}

\begin{abstract}
Many secondary schools in South Africa have elaborate school policies on learner pregnancy. Many of these policies state that in the event of a female learner falling pregnant, the said learner will be suspended from the school. The application of these policies has been challenged in the courts of law either by the parents of the learners or the Department of Basic Education in South Africa. The study used a qualitative research approach to explore the perceptions of Life Orientation teachers with regards to learner pregnancy policies and their efficiency. A purposive sample of nine Life Orientation teachers was chosen, and a focus group was used to collect data from the respondents. There were five female and four male teachers in total who participated in the study. Their age ranged from 27 to 52 years with an average teaching experience of 15.3 years. The study showed that despite the legis/ation stating that schools should be supportive of the needs of the pregnant learners at the school, teachers interviewed demonstrated their unwillingness to adhere to the law. As a result, pregnant learners are advised or coerced to stay at home for the remainder of their pregnancy as the school environment is not tolerant towards them.
\end{abstract}

Keywords: coerce; learner pregnancy; Life Orientation; policy; school; suspension

\section{INTRODUCTION}

It is a taboo in many communities for a school going child to fall pregnant while still being a learner. It is further insisted that learners falling pregnant are not participating in protective sex. Sithole, Manwa and Manwa (2013:68) refer to traditional leaders (church leaders) as being the conservative groups in society that abhor teenage pregnancy, especially among school going girls. Early teenage pregnancy results from unprotected sex which also exposes affected learners to a number of dangerous infections such as the Human Immuno-Deficiency Virus (HIV) and Acquired Deficiency Syndrome (AIDS) (Prinsloo \& Moletsane, 2013:11; Selesho \& Modise, 2012:185; van Rooyen \& van der Berg, 2009:93; Vivancos, Abubakar, Phillips-Howard \& Hunter, 2013:55). South Africa, being one of the African countries experiencing high levels of HIV/AIDS infections, is subject to high costs of medical care and other government interventions. The future of the learners who fall pregnant might remain bleak as some might drop out of the education system as they might not receive support from their parents and the community in which they live (Nash, 1990:149; Pitso \& Kheswa, 2014:539; Willan, 2013:145). Based on Willan's (2013) assertions, there could be a lot of pressure put on learners who fall pregnant to terminate the pregnancy by way of abortion as is allowed in terms of The Choice on Termination of Pregnancy Act, 92 of 1996. The termination of pregnancy by teenagers might further put learners at risk due to unscrupulous street doctors who claim to perform legal abortions (Constant, Grossman, Lince \& Harries, 2014:303). The sex pedagogy in public schools continues and is focused on aspects such as life skills and sex education (National Education Policy Act, 27 of 1996). 
Matlala, Nolte and Temane (2014b:85) point out that despite a consistency of the sex pedagogy in schools, the number of learners who fall pregnant continues to rise. Cohorts of factors have been singled out as the source of learner pregnancy. Chinyoka and Naidu (2013:203), Kheswa and Pitso (2014:564), Molosiwa and Moswela (2012:268), and Mphale (2014:186) maintain that poverty, single-headed homes and substance abuse are the main reasons why female learners are likely to fall pregnant. Furthermore, Naong (2011:906) claims that the child support grant in South Africa has deliberately encouraged young girls to fall pregnant in order to receive a monthly stipend or grant from the government. The view of Naong (2011:906) is that the government social grant provided for defeats the means to teach teenagers to abstain from sexual intercourse at an early age. As a deterrent, the South African Schools Act (SASA), 84 of 1996, gives the school governing bodies (SGBs) the authority to adopt a learner code of conduct to regulate the behaviour of learners legally.

\section{LITERATURE REVIEW}

\subsection{Learner school pregnancy policy}

Learner school pregnancy policy in this study is contextualised within the legal framework. In terms of section 8 (1) of SASA, a governing body of a public school must adopt a code of conduct for the learners after consultation with the learners, parents and educators of the school. Furthermore, section 8 (2) specifies that a code of conduct must be aimed at establishing a disciplined and purposeful school environment dedicated to the improvement and maintenance of the quality education. It is the view of this study that SGBs who suspend learners who fall pregnant are creating a negative environment that does not enhance a purposive learning and disciplined environment. Against the rationale provided for suspending pregnant learners, it must also be taken into consideration that section 3 of SASA stipulates that learners in South Africa are compelled to attend school, and it is an offence for anyone who prevents such a learner from attending school without a just cause. Any person found guilty of such an offence could be imprisoned for a period not exceeding six months or be fined by a court of law. Similarly, SASA permits pregnant learners to stay in school throughout their pregnancy and to return to school after childbirth. In addition, the Promotion of Equality and Prevention of Unfair Discrimination Act, 4 of 2000 stipulates that school learners who become pregnant should not be unfairly discriminated against.

Phaswana-Mafuya, Tabane and Davids (2016:423) and Moyagabo and Chireshe, 2013:145) are of the view that learner pregnancy policies could be regarded as discriminatory as they are silent about teenage fathers. As such, many learner pregnancies could be a reflection of the societally engendered prejudices and the girl who becomes pregnant is responsible for the pregnancy, hence the punishment. It is the view of this study that learner pregnancy policies are punitive measures to curb the spread of female learner pregnancies and could be seen as a response to the corrective measure on sex pedagogy in public schools. This assertion is based on the notion that learners who fall pregnant are likely to leave the school on their own account, their parents' decision, or are coerced to leave because the schooling environment might be unbearable for that particular learner (Malahlela \& Chireshe, 2013:145; Matlala, Nolte \& Temane, 2014a:5; Mazibuko \& Nkune, 2014:383).

Moreover, the schools force the learners to leave the school by applying their code of conduct which might articulate that no learner should fall pregnant while being a learner. Mashishi and Makoelle (2014:377) view this form of suspension of pregnant learners from the school as a form of deliberate exclusion. This view is supported by the Welkom High School and Harmony High School learner pregnancy policies which were challenged by the Free State Department of Education in the Free State High Court. According to the leaner code of conduct, the policy stated that learners who fall pregnant while being learners at the school should be suspended. The two schools suspended two learners who fell pregnant while being learners at their schools as per their learner code of conduct. The Department of Education argued that the school policies violate section 29 of the Constitution (RSA), 
the right to education, and section 3 of the South African Schools Act, 84 of 1996, which refers to compulsory attendance at school. Subsequently, the Head of Department (HOD) for the Free State Department of Education ordered the two school principals to allow the two suspended learners to return to the schools. The defence of the Harmony and Welkom schools' governing bodies was that they were within their legal authority as per section 8 of SASA, which compels the SGBs to adopt a learner code of conduct. The Free State High Court ruled in favour of the two schools stating that the Free State Department of Education's HOD acted ultra vires in that the department did not have the authority to overrule the decisions of the two school governing bodies.

Faced with possible expectations from other schools, the Free State Department of Education took the matter to the Constitutional Court to challenge the decision of the Supreme Court. Early in March 2013, the Constitutional Court overturned the Supreme Court's decision and ruled that the SGBs' code of conduct for learners impaired the right of pregnant female learners to education as stipulated in section 29 of the Constitution (RSA). The Constitutional Court for the case 'The Head of Department: Department of Education Free State $v$ Welkom High School and Harmony High School' stated that the pregnancy policies and the decisions based on them were indeed unlawful, unconstitutional and invalid. Furthermore, the judge contended that the SGBs' policies which resulted in pregnant female learners being suspended from school defeated the provisions of section 9 of the South African Schools Act, 84, 1996 and section 29 of the Constitution. The decision of the Constitutional Court in the aforementioned case has set the precedence that should be followed and implemented by public schools in South Africa until such time that another court of the same status decides otherwise. Consequently, South African public schools are faced with the challenge of aligning their school policies on learner pregnancy to conform to SASA and the Constitution (RSA).

\section{METHODOLOGY}

\subsection{Research questions}

The study sought to address the following research questions:

- What is the nature of the perceptions of Life Orientation teachers towards learner pregnancy policies in public schools?

- What are the perceptions of teachers towards learner pregnancy in schools?

- How effective are the learner pregnancy policies in secondary schools in the Lejweleputswa district of the Free State Province?

\subsection{Research design}

The study used a qualitative research approach to determine and analyse the perceptions, attitudes and experiences of Life Orientation teachers with regards to learner pregnancies in their schools. This view is consistent with Babbie (2011:323), Hennink, Hutter and Bailey (2011:19), and Silverman (2011:59), stating that qualitative research endeavours to portray a socially constructed nature of reality and seeks to answer questions that stress how social experiences are socially constructed and given meaning.

\subsection{Sample}

Nine Life Orientation HODs were sampled using a purposeful sampling technique (Flick, 2018:19). There were five female and four male Life Orientation HODs ( $N=9$ ). Data was recorded through a voice recorder and was later transcribed. A sample of nine learner school policies were also used to triangulate the responses of the Life Orientation HODs.

\subsection{Data collection}

A focus group interview was conducted with nine Life Orientation HODs. Various researchers (Gill, Steward, Treasure \& Chadwick, 2008:292; King \& Horrocks, 2010:213; LeBlanc, 
2010:1622, Madriz, 2003:378) posit that focus group interviews allow the researcher to gain insight into the opinions, views, attitudes and experiences of the interviewees. The responses of the Life Orientation HODs were followed by document analysis of the relevant learner pregnancy policies.

\subsection{Ethical considerations}

Flick (2014:48) infers that conducting research with human beings should be a moral inquiry. King and Horrocks (2010:107) refer to utilitarian epistemology as a case of benevolence, where the researcher's responsibility is to secure the well-being of the participants by avoiding harm. Permission to conduct the research was sought from the Free State Provincial Department of Education and from the school principals. The research participants completed an informed consent form and the purpose of the study was explained to them. Hammersley and Traianou (2012:76) agree that research participants should not be forced to participate in the research study or participate under false pretence.

\subsection{Data analysis}

Data were thematically analysed by employing open coding procedures (Flick, 2018:154). The thematic data analysis organises, categorises and summarises data in meaningful themes in order to gain the understanding of the Life Orientation teachers interviewed. The themes were assigned codes and data was categorised.

\section{RESULTS AND DISCUSSION}

The findings of the study were divided into two sections, namely the document analysis of the nine school policies reviewed and the categories of themes that emerged from the focus group interviews.

\subsection{Learner pregnancy policy}

Under this theme, the sub-themes that were interrogated included the availability of the policy, learners being aware of the policy, and parents and teachers being aware of the policy. Seven out of the nine learner pregnancy policies at the nine schools sampled did not have specific learner pregnancy policies. The five that had learner pregnancy policies would not elaborate on how the policies are implemented and how the rights of learners to education are safe-guarded. More so, the Life Orientation teachers seemed not to know whether learners were aware of the policies affecting them or not.

\subsection{Learners' pregnancy policy and discrimination}

Life Orientation teachers were asked whether the learners' pregnancy policy included male learners or targets only female learners. Studies conducted show that in most cases, female learners are discriminated against and male learners who impregnate female learners are exonerated from taking the responsibility. As such, there is an extensive pressure placed on the shoulders of female learners to take the blame and responsibility for the pregnancy. In some cases, as indicated in the research, unsupported, pregnant female learners are forced to secretly perform illegal and unsafe abortions.

\subsection{Effectiveness of the policy}

This theme concentrated on the efficiency of the school policy to discourage early learner pregnancy at the school. As previously indicated, interviewed Life Orientation teachers claimed that their schools had learner pregnancy policies, however, the review of their policies showed that their policies were not specific and convincing on how they wish to address this behavioural problem at the school. Consequently, their school policies could not be viewed as being effective. This view is supported by a 44-year old male teacher with 16 years of teaching experience by observing the effectiveness of the learner pregnancy policy by stating: 
The pregnancy policy is not that effective, because it does not have control over the learners as to what they want to do with their bodies. It is difficult, because learners will engage in sexual activities anyway outside the school premises; this is not the problem of the school alone, it is the societal problem.

The view expressed by the male teacher is consistent with researchers who have observed that there are a number of contributing factors that lead to learner pregnancy, such as a lack of discipline at home, pressure from the media, as well as availability and exposure to explicit sex material and pornography which can be easily accessed through various avenues. However, van Rooyen and van den Berg (2009:91) are of the view that teachers are not sufficiently trained to implement learner pregnancy policies in their schools. This view is supported by Phasa and Megogo (2012:325) who state that some teachers are unwilling to teach learners about sex, HIVIAIDS and teenage pregnancy because of their own conservative values.

\subsection{Effectiveness of the life skills programme at the school}

In order to curb the increase in learner pregnancy in schools, the Department of Basic Education in South Africa introduced a life skills programme through the Life Orientation curriculum to teaching learners about their bodies. Amongst other contents covered in the Life Orientation curriculum, sex pedagogy and life skills are taught to learners and the aim of this approach is to encourage all subject teachers to teach it across the curriculum. However, research shows that not all teachers are capable of covering these subject matters in their classes. Other teachers do not have enough experience as to how sex education should be taught to learners. This is the view of a 56-year old male veteran teacher with 32 years of teaching experience:

Talking about sex to the teenage learners is a waste of time, these kids they already know what you are talking about and in some instances, they seem to know more than you do. So for them, it see who knows more than whom. It is really difficult, at times they will just giggle because you are talking about something that excites them and they do not feel ashamed about it.

This view is supported by another 34-year old male teacher with nine years' teaching experience when he said:

From my experience, it is important that I don't waste time by talking about sex issues in the class. It might be viewed as if you are encouraging learners to be more aware or be involved in sexual activities. So, it is important that I concentrate on the subject that I am teaching.

\subsection{Teachers' efficacy to deal with pregnancy cases}

It is the general assumption that teachers should act in loco parentis towards their learners, that is to care for their well-being and instil discipline in them. However, it emerged that not all the teachers are capable of this. In general, teachers are trained and taught to teach didactic subjects that they specialise in. Though it is expected that they should assist and counsel learners who fall pregnant at the school, not all of them are capable or willing to do this. The interviewed teachers showed concern as they are under pressure to perform well in the subjects that they teach and not to look after the pregnant learners at the school. It was stressed that they could only comfort and show support for them. A relatively young female teacher (28 years) with five years' teaching experience says:

I think it is the responsibility of the pregnant female learner which must take care of her, and not that of teachers, we do our part as teachers and the school, finally the family of the learner must take responsibility of their kid. I feel teachers are sometimes blamed or expected to take responsibility for things that are outside their scope of their work. 
Furthermore, a 44-year old female teacher with 14 years' teaching experience echoed:

I think the classroom should not be turned into a maternity ward where teachers are expected to be nurses. Teachers should not be pressured to play the role of nurses. When a female learner falls pregnant, it is not a mistake, there are clinics all over and birth control measures are easily available for them to use should they decide to be adults. If a learner falls pregnant being a learner at the school, such a learner should be encouraged to take maternity leave from the school and stay at home with her parents to look after.

This statement was supported by a 52-year old female teacher with 28 years of teaching experience and is also the Head of the Department for Life Orientation at the school:

You see, not all the schools are having enough resources to look after pregnant female learners, there are no sick rest rooms at the school where I teach. My experience tells me that pregnancy is a complicated process and sometimes there are complications and the school is unable to respond immediately to the emergency. This might be blamed on the school and not the learner who is pregnant.

\subsection{Learner pregnancy as a barrier to learning}

During the focus group interview, teachers showed a concern that learner pregnancy at the school was a serious barrier to effective learning for the particular learner concerned. Most of the prenatal period is monitored by health workers at the local clinics. This results in female learners being absent from school for several days and they fall behind in their lessons as teachers are not readily willing to offer extra classes.

A 42-year old female teacher with 16 years of teaching experience reflected:

Though one will want to assist female pregnant learners with extra classes for the lessons they missed, it is not always possible. In my experience, very few learners make it at the end of the year, many come back the following year to repeat the grade they failed. In some instances, others do change schools because of the stigma that is associated with early motherhood.

This statement shows that many public schools in South Africa are not conducive and enabling environments for learning to take place. According to Temane and Osher (2014:3), when learners feel emotionally unsafe they are likely to avoid school or opt to drop out of school. This view is embraced by van Vollenhoven and Els (2010:109) who state that HIV/AIDS infected learners as well as pregnant learners are likely to face violation of their rights to dignity and being treated equally by teachers and learners alike. Matlala, Nolte and Temane (2014a/b:87) elaborate that pregnant learners are pressured to quit schooling as a result of the shame they suffer.

\subsection{Learner pregnancy as a violation of the rights of other learners}

Although the basic education policy on prevention of learner pregnancy at schools and the ruling of the Constitutional Court in the case of the Harmony and Welkom Schools are highlighting that pregnant learner' rights to education should not be infringed or violated, it is yet to be argued how pregnant learners violate the rights of other learners (van Vollenhoven \& Els, 2010:110). When questioned about the extent to which they believe other learners' rights to education are violated by the presence of pregnant learners at the schools, the interviewed teachers showed a sense of uneasiness and discomfort. A 27-year old male teacher with four years' teaching experience responded by stating the following:

I don't think a pregnant learner violates the rights of other learners at the school, particularly in the classroom, though I feel more attention and focus is based on 
the pregnant learner. However, I do feel that it is the learner who is pregnant in the class whose rights are more violated as she is mostly teased, looked at differently by teachers and learners and gossiped at behind her back. I pity those learners who fall pregnant because they go through a lot. It is only a few with tough skins who are able to survive the period of pregnancy while being at the school, and academically they perform badly.

Matlala, Nolte and Temane (2014a/b:88) and Willan (2013:53) allude that teachers are encouraged to advise parents to withdraw their pregnant children from school, especially when they suspect that the health of such learners is at risk.

\subsection{Parental support and aid}

It is the responsibility of each parent to make sure that his/her child does not fall pregnant while being a learner at school. This responsibility is shared with the teachers at the school through various life skills programmes and instilling discipline amongst the learners. In a study conducted by Selesho, Twala and Modise (2012:128), it was found that teachers identified parental support and role as a barrier in the fight against teenage pregnancy in most of the public schools. As such, it is expected that parents should visit the school to report the pregnancy of his or her child to teachers and the school (Haglund, 2006:373). However, the school policy on learner pregnancy reviewed did not elaborate on the role that the parents should play in the event that their child falls pregnant. Moreover, the interviewed teachers emphasised that it is primarily the responsibility of parents to make the necessary arrangements for their child with the school in the event of pregnancy.

A 43-year old female teacher with 15 years of experience responded:

The school should know upfront what the parent is going to do with his or her child and what kind of support are going to be given to the learner. It should be left to the school alone as if the school has all the answers that parents do not have.

This view is supported by Matlala, Nolte and Temane (2014a/b:88) as well as Lutya (2012:89) who state that parental communication is important for the purpose of interacting, supervising, guiding and teaching their teenagers about issues that affect their lives from an early age. The view of Lutya (2012:89) suggests that parents should take full responsibility for their children and not leave the problem up to the school.

\section{SUMMARY AND CONCLUSION}

The findings of this study suggest that learner's pregnancy policies in secondary schools are perceived with mixed feelings by the teachers. Despite efforts by the Department of Basic Education in South Africa, it seems that the perceptions and attitudes of teachers have not changed towards pregnant learners in public schools. Furthermore, the study reveals that teachers perceive learner pregnancy negatively and believe they do not possess the skills to effectively deal with the problem. This is of great concern since the rights of pregnant learners to continue with their education seem to be violated by teachers who disregard the law as well as the school policies. In addition, it appears that schools continue to be unconducive places for learning for pregnant learners as they continue to be faced with discrimination, labelling, and feelings of embarrassment. Respondents in this study further affirm that parents should take full responsibility for the upbringing of their children should a child fall pregnant while being a learner at school. 


\section{References}

Babbie, E. 2011.The Basics of social research. Belmont, CA: Wadsworth Cengage Learning.

Chinyoka, K. \& Naidu, N. 2013. Uncaging the caged: Exploring the impact of poverty on the academic performance of form three learners in Zimbabwe. International Journal of Education Science, 5(3):271281. https://doi.org/10.31901/24566322.2013/05.03.13.

Constant, D., Grossman, D., Lince, N. \& Harries, J. 2014. Self-induction of abortion among women accessing second trimester abortion services in the public sector, Western Cape Province, South Africa: An exploratory study. South African Journal of Medicine, 104(4):302-305. https://doi. org/10.7196/samj.7408.

Department of Education 2007. Measures for the prevention and management of learner pregnancy. Government Press: Pretoria.

Department of Education, Free State Province v Welkom High School \& Harmony High School (766 7 767/2011) [2012] ZASCA 150 (28 September 2012).

Flick, U. 2014. An introduction to qualitative research (5 $5^{\text {th }}$ Edition). London, UK: Sage Publications.

Gibbs, G. 2007. Analysing qualitative data. London, UK: Sage Publications.

Gill, P., Stewart, K., Treasure, E. \& Chadwick, B. 2008. Methods of data collection in qualitative research: Interviews and focus groups. British Dental Journal, 204(6):291-295. https://doi.org/10.1038/bdj.2008.192.

Guldal, D., Mevsim, V., Gunvar, T. \& Ozcakar, N. 2012. The perspectives of peer educators: What are their experiences, feelings, and thoughts? Health, 4(7): 349-356. https://doi.org/10.4236/health.2012.47057.

Haglund, K. 2006. Recommendations for sexuality education for early adolescents. Journal of Obstetric, Gynaecologic, and Neonatal Nursing, 35(3):369-375. https://doi.org/10.1111/j.1552-6909.2006.00048.x.

Hammersley, M. \& Traianou, A. 2012. Ethics and educational research. British Educational Research Association on-line resource.

Kheswa, J.G. \& Pitso, T.J. 2014. Psychological well-being and sexual behaviour of South African teenage mothers: An overview. Mediterranean Journal of Social Sciences, 5(10):563-568. https://doi.org/10.5901/ mjss.2014.v5n10p563.

King, N. \& Horrocks, C. 2010. Interviews in qualitative research. London, UK: Sage Publications.

Kvale, S. 2007. Doing interviews. London, UK: Sage Publications.

LeBlanc, P.R. 2010. A practical approach to qualitative interviews. The Qualitative Report Volume, 15(6):16211623.

Lutya, T.M. 2012. The importance of a stable home and family environment in the prevention of youth offending in South Africa. International Journal of Criminology and Sociology, 1:86-92. https://doi. org/10.6000/1929-4409.2012.01.8.

Madriz, E. 2003. Focus groups in feminist research. Collecting and interpreting qualitative materials. London, UK: Sage Publications.

Mashishi, N. \& Makoelle, T. 2014. Inclusion or exclusion of teenage pregnancy: A comparative analysis of Namibia and South African schools' pregnancy policies. Mediterranean Journal of Social Sciences, 5(14):375-379. https://doi.org/10.5901/mjss.2014.v5n14p374.

Matlala, S., Nolte, A.G.W. \& Temane, M.A. 2014a. The need for a model to facilitate health for pregnant learners attending secondary schools in South Africa. Mediterranean Journal of Social Sciences, 5(25):83-91. https://doi.org/10.5901/mjss.2014.v5n25p83.

Matlala, S., Nolte, A.G.W. \& Temane, M.A. 2014b. Secondary school teachers' experiences of teaching pregnant learners in Limpopo Province, South Africa. South African Journal of Education, 34(4): 1-11. https://doi.org/10.15700/201412052112.

Mazibuko, M.E. \& Nkune, N. 2014. Understanding HIVIAIDS and STIs as related to sexually risky behaviour by higher education institutions students: A literature review. Mediterranean Journal of Social Sciences, 5(14):380-385. https://doi.org/10.5901/mjss.2014.v5n14p380.

Mhele, K. \& Natal, A. 2014. Rates and predictors of school pregnancy among black women in the North West Province, South Africa. Supply on Population Issues in South Africa, 28(1):636-647. https://doi. org/10.11564/28-0-521.

Molosiwa, S. \& Moswela, B. 2012. Girl-pupil dropout in secondary schools in Botswana: Influencing factors prevalence and consequences. International Journal of Business and Social Science, 3(7):265-271. 
Moyagabo, K.M. \& Chireshe, R. 2013. Educators' perceptions of the effects of teenage pregnancy on the behaviour of the learners in South African secondary schools: Implications for teacher training. Journal of Social Sciences, 37(2):137-148. https://doi.org/10.1080/09718923.2013.11893212.

Mphale, L.M. 2014. Prevalent drop-out: A challenge on the roles of school management teams to enhance students' retention in Botswana junior secondary schools. International Journal of Business and Social Science, 5(11):178-188.

Nash, E.S. 1990. Teenage pregnancy - need a child bear a child? South African Medical Journal, 77:147151.

Phasa, N. \& Megogo, J.B. 2012. Sex education in rural schools of Mpumalanga Province, South Africa. Journal of Social Science, 31(3):319-327.

Phaswana-Mafuya, N., Tabane, C. \& Adlai, Davids. 2016. Community member perceptions of influences on teenage pregnancies. Journal of Psychology in Africa, 26(5): 419-427. https://doi.org/10.1080/143 30237.2016.1185916.

Pitso, T. \& Kheswa, J.G. 2014. The vicious cycle of teenage motherhood: A case study in Eastern Cape, South Africa. Mediterranean Journal of Social Sciences, 5(10):536-540. https://doi.org/10.5901/ mjss.2014.v5n10p536.

Prinsloo, J. \& Moletsane, R. 2013. The complexities of sex, gender and childhood in present-day South Africa: Mapping the issues. Agenda: Empowering women for gender equity, 97(27):2-12. https://doi.or g/10.1080/10130950.2013.849035.

Selesho, J, Twala, C. \& Modise, A. 2012. "Telling the story" The educators' perspective on HIV/AIDS Education in schools. Journal of Human Ecology, 40(2):125-130.

Selesho, J.M. \& Modise, A.M. 2012. Strategy(ies) in dealing with HIV/AIDS in our schools: Changing lenses. Journal of Human Ecology, 38(3):181-189. https://doi.org/10.1080/09709274.2012.11906487.

Silverman, D. 2011. Interpreting qualitative data: A guide to the principles of qualitative research. London, UK: SAGE.

Sithole, J.C., Manwa, L. \& Manwa, L. 2013. Gender equity in education: An analysis of perceptions of Masvingo urban female students, parents and teachers towards the maternity leave policy for high school girls in Zimbabwe. Journal of African Studies and Development, 5(4):64-69.

South Africa (Republic). (1996). Constitution of the Republic of South Africa, Act 108. Pretoria: Government Printers.

South Africa (Republic). (1996). South African Schools Act, 86. Pretoria: Government Press.

South Africa (Republic). (2000). The Promotion of Equality and Prevention of Unfair Discrimination, Act 4. Pretoria. Government Print.

The Head of Department: Department of Education Free State $v$ Welkom High School and Harmony High School, 766 \& $767 / 2011$.

Temane, M. \& Osher, D. 2014. Schools as enabling environments. South African Journal of Education, 34(4):1-5.

Uys, T. \& Puttergill, M. 2005. Sampling. In D Rossouw (eds).Intellectual tools skills for the human sciences. Pretoria, South Africa: Van Schaik.

Van Rooyen, L. \& Van den Berg, D. 2009. Implementation of an HIV/AIDS programme in South African schools: Strengths and weaknesses. International Journal of Adolescence and Youth, 15:81-102. https://doi.org/10.1080/02673843.2009.9748021.

Van Vollenhoven, W.J. \& Els, C.J. 2010. Do South African HIV/AIDS educational policies and praxis promote the best interest of the child? Journal for Juridical Science, Special Issue, 106-122. https://doi. org/10.4314/jjs.v35i2.64587.

Vivancos, R., Abubakar, I., Phillips-Howard, P. \& Hunter, P.R. 2013. School-based sex education is associated with risky sexual behaviour and sexually transmitted infections in young adults. Public Health, 127(1):53-57. https://doi.org/10.1016/j.puhe.2012.09.016.

Willan, S. 2013. A review of teenage pregnancy in South Africa - Experiences of schooling and knowledge and access to sexual reproductive and health services. A Review of Teenage Pregnancy in South Africa, Partners in Sexual Health, 1-63. 